\title{
STABILITY FOLLOWING FRACTURE-DISLOCATIONS OF THE CERVICAL SPINE
}

By Prof. J. M. del Sel, Dr. J. B. Cibeira, Dr. R. O. Espagnol, Dr. G. M. Del Sel and Dr. H. J. DEL SEL

The First Chair of Orthopaedics and Traumatology, School of Medicine, Buenos Aires and the Instituto Nacional de Rehabilitación del Lisiado, Buenos Aires, Rep. Argentina

IN 1970, Crue published his 20 years' experience with a conservative approach in 87 patients, pointing out that surgical fusion had not been proved to be a procedure of choice.

In our own experience of over 25 years, we have dealt with almost twice the number of cases. In every case treated conservatively, spontaneous fusion followed as a rule, without interfering with the rehabilitation programme. Although the conservative approach was deliberately chosen as a means of treatment, there were a number of cases in which surgical fusion would have been technically and mechanically unsound.

A large number of cases that came to our hands after laminectomy followed by anterior or posterior fusion or both, never showed any improvement as a direct result of the operation. One of the arguments that has been claimed for early surgical fusion is, that it facilitates the immediate rehabilitation of the patient. Early rehabilitation of the patient can be started immediately without any surgery. If skull traction is applied, apart from being mobilised every two hours, the patient is also encouraged to rotate his head, both as an exercise and to determine for himself the most comfortable position.

We have found that skeletal traction by means of a de Anquin or Urrutia stirrup has not only been very well tolerated by the patient, but also facilitates the periodical turning and does not interfere with the continuous nursing care. The patient will soon start active flexo-extension exercises. In doing so, by the time the traction is discontinued-four to six weeks-he will be able to hold his head in any desired position.

In recent cases, the dislocation is easily reduced. Traction has been kept for periods varying from 20 to 45 days. Once traction is discontinued, an adjustable leather collar or a minerva plaster jacket, depending on the case, is worn for several weeks. When active exercises are encouraged, the reduced position is maintained and X-ray examination will soon show spontaneous fusion due to ossification of the anterior longitudinal ligament.

We do not agree with the minerva plaster jackets which immobilise the forehead, as they only lead to the necessity of liberating the chin to perform masticatory movements, the immediate consequence being the loss of the all important hold under the mandibular area. With the type of plaster that we advocate, the patient can freely open his mouth by raising his head. After a few days or weeks, they can even lift the chin from the plaster. The possibility of lifting the head will not 
impair immobilisation, but on the contrary this active movement will strengthen the muscles and enhance bone formation achieving auto-stabilisation.

The treatment of fractures of the odontoid process has given rise to many a controversy. Those who maintain that the dens unites under adequate immobilisation, find opposition among the admonishers of surgical fusion.

When there are clinical signs of a fracture of the dens, it is of the utmost importance to get X-ray films of excellent quality in the trans-oral view.

For the treatment of this lesion we want to emphasise the important of a wellmoulded minerva jacket. The plaster must firmly hold the chin and occipital area, leaving the forehead and parietal areas free, as to allow the patient to open his mouth unobstructedly.

In our experience surgical fusion has never been used. Bony fusion has taken place in almost every case in a period of three months. Good prognosis can be anticipated when the patient can actively raise his chin from the plaster and initiate some rotatory movements by the end of the second month.

\section{Scheme of Treatment:}

I. Fracture-dislocations of the upper cervical spine without neurological signs. Minerva plaster jacket for a period of three months.

2. Fracture-dislocations of the upper cervical spine with neurological signs at a lower level. Skull traction for three to four weeks followed by an adjustable leather collar to complete three months. If recovery is well advanced and the patient is already ambulatory, a minerva plaster jacket might be a preferable alternative.

3. Fracture-dislocations of the lower cervical spine without neurological involvement. Minerva plaster jacket for three months.

4. Fracture-dislocations of the lower cervical spine with neurological involvement. Skull traction for three to six weeks according to the magnitude of displacement, course of clinical progress and early radiological signs of stability. Once traction is discontinued an adjustable leather collar is worn to complete a period of three months, or for a longer period if necessary.

Dislocations of $\mathrm{C}_{7}-\mathrm{T}_{1}$ and even $\mathrm{C}_{6}-\mathrm{C}_{7}$ are often missed on the first examination mainly when patients are neurologically symptomless. Sometimes they are recognised several months after the original injury, when the fusion or fibrous stability of the spine has taken place. This is due to the difficulty of obtaining lateral films of good quality to visualise the whole lower cervical spine. However if there is any suspicion of an injury at that level, the anteroposterior view may uncover the displacement by showing the inversion of the neural arch, provoked by the listhesis.

One point to be emphasised is that the neurological level does not always correspond to the level of the fracture-dislocation. A case of a man in his thirties who sustained an extension injury, fracture-dislocation $\mathrm{C}_{6}-\mathrm{C}_{7}$ with complete motor paraplegia at level $\mathrm{T}_{4}$, had complete function of the upper limbs and partial sensory loss below $\mathrm{T}_{4}$, is particularly demonstrative that orthopaedic treatment was the only alternative because the mechanical conditions of the spine prevented any surgery. There was marked posterior dislocation not suitable for an anterior Cloward type fusion or for a posterior fusion, since wiring of the spinous processes 
would have increased the posterior displacement. He was put in traction for five weeks and then on an adjustable leather collar for a total of three months. There was complete recovery and spontaneous fusion of the fractured area was soon visible in the lateral films.

Although it has also been stated that surgical fusion of the cervical spine is one of the simplest and safest procedures, we believe that a surgical procedure cannot be recommended solely on the grounds of simplicity. On the other hand, there are obvious risks implied in narcosis and handling of the patient during the operation itself, not to mention the complications that often arise postoperatively among the enthusiasts of surgery.

Still some authors have admitted the recurrence of the displacements when surgery is not technically perfect or when postoperative immobilisation is not maintained for an adequately prolonged period.

Verbiest, one of the most enthusiastic supporters of cervical fusion for traumatic lesions of the cervical spine with and without associated neural deficits, accepts that in at least two out of the six deaths from a total of 47 fusions, surgery may have contributed to the fatal outcome. Although Verbiest's paper is often quoted to justify surgical fusion on the basis of the need to achieve stability of the cervical spine, we believe that the results should not only have been considered successful because a fusion has taken place, but should also be outweighed with those obtained on a similar series treated conservatively in a shorter period of time and without taking the risks of narcosis and surgery.

With concepts similar to those of Verbiest, others like Ramadier (1963), Kahn (1959) and Robinson (1959) favour surgical fusion, while Alcibar (1963), Goidanich (1963) and Peregalli (1963) adhere to conservative treatment. It is also significant to quote Böhler (1963), who operated only II in a total series of I90 patients ( 5.8 per cent).

Our view is that surgical fusion of the spine and particularly of the cervical region for the treatment of traumatic lesions of the rachis, is more an obsession than a real therapeutic need. This trend is evidenced by the great number of papers published in orthopaedic journals, which are usually based on the prejudice that when there is no cord lesion, it should be prevented, and when there is cord involvement fusion is to be considered the method of choice.

The supporters of surgical fusion as the only means of stabilisation have been even surpassed by those advocating 'early vertebral body replacement' (Norrel, 197I). In this respect we completely agree with Frankel who has insisted that these operations are not required.

Although this type of surgery can be very useful and perhaps the only alternative in the treatment of certain tumours (de Anquin, I97I), it is not justified for a surgeon to take advantage of traumatic cases and operate with the sole scope of training.

Fusion has been advocated 'to stabilise the head', since it is argued that the tetraplegic patient needs a strong neck to hold his head in different positions. This is quite fallacious, because where the cord lesion is at level $\mathrm{C}_{4}$ or above, it is not compatible with life and on the other hand lesions comprising levels below $\mathrm{C}_{4}-\mathrm{C}_{5}$ do not damage the nerve supply to the muscles which will provide stability of the neck, i.e. rectus capitis anterior, rectus capitis posterior major, rectus capitis posterior minor, sternocleido mastoid, trapexium, obliquus capitis inferior and obliquus capitis superior. 
Of course this criteria does not hold when polio is considered, since paralysis may affect the short flexors and extensors of the head (RCA, RCPMj, RCPMn, OCS, OCI.) and therefore surgical fusion may have a place in the treatment of these patients (Perry, I959).

Patients with ankylosing spondylitis sustaining fractures of the cervical spine without neurological involvement are suitable for conservative treatment with a minerva jacket or an adjustable leather collar. On the contrary when there is a cord lesion specially when there is complete transection, the prognosis is poor with the highest incidence of mortality. Since in these patients both the neck and the rest of the body act as rigid shafts, the site of the lesion absorbing every movement, we wonder whether in these cases immediate fixation of the area could benefit nursing and even improve the prognosis. Perhaps this immobilisation could be obtained by wiring the spinous processes with the addition of bone cement. We believe this to be an interesting field for speculation.

\section{SUMMARY}

After having dealt with over I 50 cases of fracture-dislocations of the cervical spine, the authors conclude that conservative orthopaedic treatment leads to the best results. The lesions are classified in upper and lower cervical spine. The latter has been divided in two subgroups according to the presence or abscense of neurological involvement.

The importance of skull traction and of a well-moulded minerva plaster jacket is stressed. An adjustable leather collar is a useful alternative for immobilisation and exercises, favouring spontaneous fusion. In neither group, should surgical fusion be considered a routine procedure.

\section{RÉsUMÉ}

Après avoir traité plus de cent cinquante cas de fractures par tassement de l'épine cervicale, les auteurs concluent que c'est le traitement orthopédique de conservation qui donne les meilleurs résultats. Les lésions sont classées en lésions supérieures et inférieures de l'épine cervicale. Les lésions inférieures ont été divisées en deux sous-groupes selon la présence ou l'absence d'atteinte neurologique.

L'importance de la traction crânienne et d'un corset plâtré Minerva bien moulé est soulignée. Un collier de cuir adaptable est une alternative utile pour l'immobilisation et les exercices, en favorisant la fusion spontanée. Dans aucun des groupes, la fusion chirurgicale ne devrait être considérée comme une méthode de routine.

\section{ZUSAMMENFASSUNG}

Nach Behandlung von I50 Luxationsfrakturen der Halswirbelsäule kommen die Autoren zu dem Schluss, dass die konservative Behandlung die besten Resultate erzielt. Die Läsionen sind in obere und untere Zervikalläsion eingeteilt.

Die Bedeutung von Kopfzug und in Läsionen mit leichten Rückenmarksschädigung des Minervakorsetts wird betont. In keinem Fall ist chirurgische Fusion als Routinmethode angezeigt.

\section{REFERENCES}

Alcibar, E. (1963). Perfect end result of a dislocation with fracture of the cervical spine. $9^{\circ}$ Congrés Internationale de Chirurgie Orthopedique (Vienne). Imprimerie des Sciences, Bruxelles, 9, 343-344. 
ANQuin C. D. DE. (I97I). Quiste óseo aneurismático de la columna cervical con complicación medular. Bol. y Trab. Soc. Arg. de Ortop. y Traumat. 36, 289-294.

CAmeron, B. (1970). Cervical neurosurgical non-fusion. The American fournal of Orthopaedic Surgery, 12, 4-5.

Cheshire, D. J. E. (I969). The stability of the cervical spine following the conservative treatment of fractures and fracture-dislocations. Paraplegia, 7, 193-203.

Cibeira, J. B. (1969). Rehabilitación integral de 4I2 pacientes con lesiones nerviosas intravertebrales por trauma o enfermedad. Educación técnica y comunitaria. Tesis de Doctorado, Facultad de Medicina de Buenos Aires. Un tomo, 209 pp. (1969).

CRUE B. L. JR. (I970). Cervical spine fracture: 20 years' experience with a conservative approach. The American Fournal of Orthopedic Surgery, 12, 8-I2 and 43-44.

Forsyth, H. F., AleXANDER, E. JR., Davis, C. JR. \& UNDERDAL, R. (I959). The advantages of early spine fusion in the treatment of fracture-dislocations of the cervical spine. $\mathcal{F}$. Bone \& foint Surgery, 4IA, 17-36.

Frankel, H. L. (197I) Discussion. Proceedings 18th Vet. Adm. Spinal Cord Injuries Conference, 40.

Frankel, H. L., Hancock, D. O., Hyslop, G., Melzak, J., Michaelis, L. S., Ungar, G. H., VerNoN, J. D. S. \& WALSH, J. J. (1969). The value of postural reduction in the initial management of closed injuries of the spine with paraplegia and tetraplegia. Part I. Paraplegia, 7, I79-192.

Fried, L. C. (I973). Atlanto-axial fracture-dislocations, failure of posterior CI to C2 fusion. F. Bone $\&$ foint Surgery, 55B, 490-496.

GoIdanich, I. F. (1963). Fractures of the cervical spine. $9^{\circ}$ Congrés Inter, de Chirur. Orthopedique (Vienne), 9, 361.

GutTMANN SIR L. (I966). Traumatic paraplegia and tetraplegia in ankylosing spondylitis. Paraplegia, 4, 188-203.

GutTMANN SIR L. (1969). Spinal deformities in traumatic paraplegics and tetraplegics following surgical procedures. Paraplegia, 7, 38-58.

Hardy, A. G. (1969). Discussion. Paraplegia 7, 5I-52.

Harris P. (1969). Discussion, Paraplegia, 7, 54.

KAHN, E. A. (I959). Editorial on spinal cord injuries. F. Bone E foint Surgery, 4IA, 6I I.

NoRRELL, H. (I97I). The role of early vertebral body replacement in the treatment of certain cervical spine fractures. Proceedings I8th Veterans Adm. Spinal cord intern. Conference, 35-4I.

Peregalli, P. F. (I973). Injuries of cervical spine. $9^{\circ}$ Congres Intern. de Chirurg. Orthop. 9, 362 .

Perry, J. \& Nickel, V. L. (I959). Total cervical spine fusion for neck paralysis. F. Bone $\mathcal{G}$ foint Surgery, 4I A, 37-60.

Ramadier, J. O. \& Bombart, M. (I963). Traitement sanglant et non sanglant des lesions traumatiques du rachis cervical sans lesions nerveuses. $9^{\circ}$ Congres Internat. de Chir. Orthop. (Vienne), 9, 253-28I.

Risolia, A. A. \& Cuevillas, A. R. R. (I959). Luxofractura cervical en una espondilitis reumatoidea. $2^{\circ}$ Congreso Argentino Ortop. y Traumat. 2, 267-272.

Robinson, R. A. (1959). Editorial-Fusions of the cervical spine. F. Bone E foint Surgery, 4IA, I-6.

Russe, O. \& Jahna, H. (I963). Treatment of the fractured odontoid process. $9^{\circ}$ Congr. Internat. de Chir. Orthop. (Vienne), 9, 365.

Sel J. M. Del, Cibeira, J. B. \& De PaOli, J. M. (1967). Paraplejias y Iatrogenia. Rev. Ortop. y Traumat. Latino-Amer. 12, 45-60

Sel, J. M. DEL \& DE PAOLI, J. M. (I967). El parapléjico en el Hospital General. Rev. Ortop. y Traumat. Latino-Amer. 12, I67-170.

Tадвот, H. S. (1969). Discussion. Paraplegia, 7, 54.

VERBIEST, H. (I969). Anterolateral operations for fractures and dislocations in the middle and lower parts of the cervical spine. F. Bone $\mathcal{E}$ Foint Surgery, 5I A, I489-I 530.

Watson JONES, SIR R. (1943). Fractures and foint Injuries. E. \& S. Livingstone, Edinburgh, 3 rd edition.

Wilson, P. (1963). Fracture dislocations of atlas and axis. $9^{\circ}$ Congr. de Chir. Orthop. (Vienne), 9, 315-330. 